\title{
How Multinational Banks in India Gain Legitimacy: Organisational Practices and Resources Required for Implementation
}

\section{Paul Caussat $^{1}$ (D) $\cdot$ Nathalie Prime ${ }^{2}$ D $\cdot$ Robert Wilken $^{3}$ D}

Received: 4 May 2017 / Revised: 3 September 2018 / Accepted: 14 September 2018 /

Published online: 27 June 2019

(c) The Author(s) 2019

\begin{abstract}
Liability of foreignness (LOF) refers to the difficulties and additional costs that multinational enterprises face when they operate in a foreign market. Rooted in institutional theory, extant literature has discussed isomorphism, transference, and sociopolitical activism as legitimation strategies to counteract LOF. This view relates to the macro level of firm and society, assumes passivity of subsidiaries, and neglects implementation of these strategies. Consequently, this paper aims at complementing this restrictive view through a qualitative study to explore how French multinational banks respond to LOF challenges in India, an adverse institutional environment typical of emerging markets but also unique due to strong economic nationalism and cultural traditions. As such, the present article contributes to the institutional research stream by (1) presenting an empirical investigation at the micro level of subsidiary organisational practices to operationalise legitimation strategies in managerial terms; (2) revealing rhetoric proactive strategies beyond the passive or reactive paths identified previously; and (3) discussing the internal implications of implementing legitimation strategies directed at external recipients within the intraorganisational network of multinational banks, using the resource-based view.
\end{abstract}

Keywords Legitimation by isomorphism - Legitimation by transference $\cdot$ Liability of foreignness · Organisational practices - Rhetoric legitimation strategy

Paul Caussat

paul.caussat@rhul.ac.uk

1 Royal Holloway University of London, Egham, UK

2 ESCP Europe, Paris, France

3 ESCP Europe, Berlin, Germany 


\section{Introduction}

The banking industry represents an exceptional context to investigate the socalled liability of foreignness (LOF) that is, the difficulties and additional costs that multinational enterprises (MNEs) encounter when they operate in a foreign market (Zaheer 1995). First, as a tool for public policy implementation that involves money creation and circulation-an attribute of national sovereignty as important as defence or internal security-banking is in essence a politicised activity (Cole 2009; La Porta et al. 2002) that needs to remain under the control of local authorities. Second, foreign bank entry increases local competition and pushes local banks towards less profitable customer segments (the 'creamskimming' effect) (Gormley 2010; Mian 2006). Third, multinational bank (MNB) subsidiaries may act as a transmission channel of financial shocks (e.g., the 2008 financial crisis) to the local market that the government tries to minimize (Jeon et al. 2013). In addition, the banking business essentially involves collecting and lending money to people, corporations, or public bodies, which requires access to 'soft' information (i.e., knowledge about local customers' expectations and capacity to reimburse) and familiarity with which they can build mutually trustful relationships. In this regard, domestic banks are more familiar with local customs and have better access to soft information vis-à-vis foreign banking MNEs (Bhaumik et al. 2018; Claessens and van Horen 2012; Mian 2006).

The institutional literature in international business discusses strategies to mitigate the negative impact of LOF (Kostova and Zaheer 1999) by acquiring legitimacy — "the social licence to operate" (Ehrnström-Fuentes 2016, p. 434). Research to date has emphasised three legitimation strategies directed at various external sociopolitical recipients (i.e., legitimacy providers), such as the regulator and the media (Deephouse 1996): isomorphism (conformism to local institutions), transference (partnership with legitimate local actors), and sociopolitical activism (establishing relationships with host and home governments).

However, some important gaps remain in the extant literature. First, these studies view the local subsidiary as a relatively submissive actor facing institutional constraints in which the management of LOF is based on a powerless or 'passive' adaptation to local rules (which is the case for isomorphism and transference strategies). Going further in institutional theory (Kostova et al. 2008), we question the extent to which subsidiaries must remain passive; instead, we posit that, even in a context of high LOF, MNEs can proactively implement organisational practices to obtain legitimacy with sociopolitical actors.

Second, most studies on legitimacy conceptualise it as a macro phenomenon (Bitektine and Haack 2015), which implies that they mostly investigate the impact of these strategies at the macro level of the (local) society and the (multinational) firm. This perspective ignores the concrete micro level of organisational practices that a subsidiary can implement to support legitimation strategies and reduce LOF. Kostova et al. (2008) call for more agency and suggest rethinking institutional theory as less deterministic. Any strategy requires a certain amount of internal resources and the competence to make use of these resources to 
achieve a strategic objective (Johnson et al. 2017). Thus, to identify what companies actually do in their attempt to pursue a legitimation strategy, researchers should focus on the micro level of organisational practices mobilised by country managers, which would also allow for more concrete and operational managerial implications.

Third, following the same argument, the macro level of analysis does not allow us to understand how the various legitimation strategies can be implemented internally, which can affect MNCs' internal relationships between the local subsidiary and its headquarters. Country managers mobilise internal organisational practices (Dörrenbächer and Geppert 2006, 2012) to gain local strategic autonomy and to mitigate potential tensions between the need for internal resources when interacting with local sociopolitical actors and the demands for efficiency from the firm's headquarters ( $\mathrm{Li}$ et al. 2016). Consequently, research should complement the external view of legitimation strategies (which are by definition directed at recipients outside the company) with an investigation into their intraorganisational consequences. Last, we lack empirical knowledge on these micro-level processes (i.e., organisational practices).

Consequently, the present research aims at enriching the institutional theoretical framework on legitimation strategies of MNEs in their foreign country markets. To (1) facilitate identification of strategies beyond the institutional framework of isomorphism, transference, and political activism and (2) be able to ask how these strategies are implemented internally at the level of the subsidiary, we use an exploratory, qualitative case-based study of three French MNBs that operate in India and their attempts to gain legitimacy in the host environment. In so doing, this research offers the following contributions. First, we present an empirical investigation into various legitimation strategies. Hereby, we use the micro level of organisational practices to operationalise legitimation strategies in managerial terms by reflecting on how country managers use them in a context of high LOF. Second, the exploratory, qualitative research design that we use allows us to identify rhetoric proactive strategies as complementary to and distinct from the passive paths of isomorphism and transference and the reactive path of political activism. Third, using the resource-based view, we discuss the internal implications of implementing legitimation strategies directed at external recipients within the intraorganisational network of MNBs.

Our study relies on a context especially suited to investigate legitimation strategies resulting from high LOF: multinational banks (MNBs) and their subsidiaries in India. The Indian context is also particularly suitable as it represents an adverse institutional environment, which, although typical of emerging markets (Sheth 2011), is also unique due to strong economic nationalism and cultural traditions. In addition, India is a favourable environment for investors considering its economic growth has made it one of the fastest-growing large economies over the past decade.

The remainder of the article is structured as follows. We proceed with a review of the theoretical framework, including the various legitimation strategies that we aim to complement. We next present the specific societal context of our study and the methodology applied. The section on the empirical results is the heart of our article and subdivides into (external) legitimation strategies and (internal) 
intraorganisational implications. The discussion synthesises the findings and as such presents a nuanced picture of organisational practices that put various legitimation strategies (including proactive rhetoric ones), as well as internal implications, into action. We conclude by pointing towards fruitful avenues for future research.

\section{Theoretical Underpinnings}

\subsection{The Eclectic Theory and the Liability of Foreignness}

Many MNEs experience LOF, as evidenced by the vast international business literature devoted to the topic (Eden and Miller 2004; Zaheer 1995). The international business literature has discussed several solutions to the LOF problem of MNEs in general. A first stream of research shows that foreign internationalising firms can increase their local competitiveness by exploiting ownership-specific advantages (firm-specific advantages [FSAs]) that they have developed in their home country (i.e., tangible and intangible resources and competences) and that are not accessible to competition. The ownership-location-internalisation (OLI) paradigm (Dunning 2009) provides an 'eclectic view' of how firms can search for the best combination of each OLI advantage and recommends specific entry strategies accordingly (the view is 'eclectic' in the sense that it simultaneously considers all the types of advantages - namely OLI advantages - that firms can benefit from when they internationalize). Foreign MNBs typically have FSAs (relating to the ownership and internalization dimensions of the OLI paradigm) when competing abroad, especially specific knowledge and assets (e.g., technicity, foreign capital, positive country-oforigin brand reputation) (Aichner 2014; Claessens et al. 2001) and internalisation capacities (e.g., the ability to integrate banking operations efficiently between headquarters and subsidiaries). These capacities allow MNBs to control their assets more effectively, reduce asset-sharing risks, and be more cost-efficient through a wholly owned subsidiary (WOS) than they would be in a partnership with a local firm (Dunning 2009). When developing abroad in countries that display location advantages, such firms will typically choose a WOS to benefit from the combination of OLI advantages.

However, rooted in an economic perspective, this body of research is more concerned with entry mode selection and the efficiency of MNEs' investment decisions (Santangelo and Meyer 2017) than with the question of how to circumvent frequent adverse local conditions and LOF. Scholars point out that the OLI paradigm may not be sufficient in explaining internationalisation decisions to enter distant (or high LOF) markets (Buckley and Ghauri 2004; Buckley et al. 2016), as it can undermine the question of local sociopolitical dynamics around the expansion of MNEs into the targeted environment. In contexts of high LOF, foreign actors can potentially face discrimination from a range of actors, including nonbusiness entities such as the government ([Li et al. 2013] in the case of domestic firms in transitional economies) as well as other influential local actors ([Barros 2014] in the case of Petrobras when interacting with local media). This discrimination reduces the capacity to deploy and benefit from potential advantages of FSAs and may discourage the 
firm from deciding in favour of a WOS. These obstacles are particularly relevant in the banking sector, in which the regulator, a key sociopolitical actor, is more likely to grant preferential treatment to domestic actors (Claessens and van Horen 2012). Moreover, it can be difficult to benefit from the 'location advantage' (i.e., the incentive to undertake value-adding activities in a specific foreign market) when no physical production takes place in the host country (Hennart 2012), which applies to the banking sector.

\subsection{An Institutional Framework to Account for the Development of Multinational Banks in a Distant Environment}

The international business literature has a long history of investigating business networks and interfirm relationships as a determinant of firms' international expansion. In contrast, studies have focussed less on relationships between firms and sociopolitical actors (Hadjikhani et al. 2008). Using institutional theory, a second stream of literature argues that foreign firms can reduce the negative impact of LOF and increase the value of their FSAs abroad by seeking legitimacy in the local environment (Suchman 1995). Institutional theory is concerned with how institutions shape the behaviours of organisations: 'Old institutionalism' (Selznick 1996) focuses on formal institutions, dynamics, and agency, and 'neoinstitutionalism' is more concerned with cognitive processes and the reproduction of behaviours across organisations ("What makes organizations so similar?" [DiMaggio and Powell 1983, p. 147]). Organisations such as MNEs are typically driven more by social processes shaped around the quest for legitimacy than by rational and economic mechanisms, because they need to establish a trustworthy position (Hadjikhani and Sharma 1999). Such organisations need to meet the expectations of legitimacy providers to enable their existence (DiMaggio and Powell 1983; Suchman 1995). In the banking industry, the most notable legitimacy providers are regulators and the media (the latter being viewed as a barometer of civil society and normative institutions) (Barreto and Baden-Füller 2006; Deephouse 1996). Such a legitimation strategy helps foreign firms overcome their LOF and reduce the failure rate among foreign market entrants (Singh et al. 1986).

International business researchers using institutional theory have mostly considered this theoretical framework in a neoinstitutionalist perspective, thereby putting legitimacy acquisition and perpetuation at the centre of a firm's survival in a foreign environment. This research stream has mainly discussed two legitimation strategies: local isomorphism and transference. Isomorphism strategy recommends that foreign firms establish WOSs that conform to local formal and informal rules, through mimicry behaviours and adaptation of products, operations, and local organisation (Kostova and Roth 2002; Kostova and Zaheer 1999; Salomon and Wu 2012). This strategy is particularly recommended when the activity is politically sensitive, is subject to extensive regulatory scrutiny, and/or exhibits customer-centric features (all traits that characterise the banking industry). However, some researchers have criticised the local isomorphism strategy, noting that it may reduce the quality of the internal relationship with headquarters and overall firm organisational efficiency. 
Consequently, isomorphism can challenge the balance between external and internal conformity (Li et al. 2016).

In contrast, the transference strategy recommends that foreign firms partner with a local actor, often through joint venture agreements ( $\mathrm{Lu}$ and $\mathrm{Xu} 2006$ ), because the local partner can accelerate learning about the environment and its key sociopolitical actors and cultural characteristics - thereby reducing LOF-and provide the foreign partner with the desired legitimacy (Chan and Makino 2007). The choice of entering into a partnership with a local organisation is linked to the level of control required but can also serve as a means to respond to institutional pressures from local sociopolitical actors (Yiu and Makino 2002). Selecting the right partner might be challenging, given the relatively low level of local knowledge (Gaur and Lu 2007), which in fact simply creates another liability problem, namely the liability of outsidership (Johanson and Vahlne 2009). Integrating local networks to gain access to key sociopolitical actors can actually turn out to be more challenging than the liability of foreignness per se, especially in emerging markets (Elg et al. 2015), in which sociopolitical institutions (e.g., political and religious institutions, nongovernmental organisations [NGOs], local communities) often wield enormous influence (Sheth 2011). However, extant literature has mostly focussed on business networks and interfirm relationships rather than on building networks with local sociopolitical organisations (Hadjikhani et al. 2008).

\subsection{Towards a Proactive Approach to Gaining Legitimacy}

In both isomorphism and transference strategies, the local subsidiary is viewed as a relatively powerless actor facing institutional constraints. Local isomorphism refers to passive compliance with local rules, whilst transference implies a dependence on the local partner for compliance.

A third legitimation method proposed in the field of strategy (Holburn and Vanden Bergh 2008; Peng et al. 2009) puts forth the idea that firms resort to political strategies to react to local regulatory adversities and turn unfavourable regulations into favourable ones. In such an approach, political strategies are viewed as a means to actively strive for legitimacy vis-à-vis political actors. However, only a few international business studies explicitly link political strategies to the legitimacy framework (Meyer et al. 2014; Peng et al. 2009; Scott 2014). Instead, most studies on reactive legitimation strategies focus on the cultural-cognitive processes of legitimacy occurring at the macro level (legitimacy based on the society's perception of foreign organisation) (Kostova and Zaheer 1999). This perspective implies a predetermined view of MNEs' behaviour in a foreign market, with (too) little openness to study institutional changes. An exception is Edman (2016, p. 689), who, using an organisational identity approach, argues that "legitimacy in local environments need not necessarily be synonymous with conformity and isomorphism" and highlights the case in which being a foreigner does not always lead to being stigmatized, especially when foreign identity can bring value to local stakeholders. In the same vein and beyond mimicry behaviour, researchers have identified corporate social responsibility (CSR) actions as a means to gain legitimacy vis-à-vis local actors (Zhao 
et al. 2014), especially in contexts of institutional voids as a substitute for missing regulatory institutions (Rathert 2016). CSR may also be pursued with the view to protecting corporate reputation with respect to the media and NGOs who track the behaviours of multinational enterprises (King 2008).

However, these studies have remained situated at a macro organisational level, while action typically takes place at the level of individuals within the organisation. More research is needed to investigate the micro-level foundations of legitimacy (Kostova et al. 2008) by investigating how actors make sense of their context and proactively shape the conditions of their legitimacy. In particular, this research field has a limited understanding of the multiple local sociopolitical actors involved when a foreign firm seeks legitimacy. Research focusing on foreign firms' interactions with local sociopolitical actors tends to consider these actors as a whole rather than studying each of them individually. Some scholars adopt a targeted approach by specifically investigating one type of actor. For example, Wu and Salomon (2017) focus on the regulatory pressures foreign firms face in the banking industry. However, a more holistic yet detailed approach to the local environment in which foreign MNEs subsidiaries operate is necessary to account for the overall ecosystem of MNBs and shed light on how they gain legitimacy. We thus identify a need to study the behaviour of MNE subsidiaries at the micro level of actions to understand the underpinnings of subsidiary legitimation, focusing on organisational practices leveraged by internal actors (and the resources required) that relate to external sociopolitical actors. The following question comprises our study focus: Which organisational practices targeted at which specific sociopolitical actors, and requiring which kind of internal resources, do subsidiary-level actors undertake in order to gain legitimacy? Defined by Kostova and Roth (2002, p. 2016) as "an organization's routine use of knowledge for conducting a particular function", organisational practices encompass a variety of micro tools shaping a firm's strategy and behaviour such as organisational tools (e.g., reporting lines, communication), human resource management tools (e.g., recruitment, career management, evaluation and remuneration packages), marketing tools (including offering, branding, and communication), and CSR policy tools. By targeting specific local sociopolitical actors, these practices act as implementers of subsidiaries' internationalisation strategy in the host environment.

\section{Research Context and Methodology}

Overall, extant theories on how MNEs (a) manage LOF in distant markets and (b) can still make effective use of their FSAs relate to the macro level of firm and society and assume passivity of subsidiaries. They also neglect the implementation side of these strategies, especially the resources the subsidiary must obtain to support them (i.e., resource-based view of strategy) (Barney 1991). To complement this restrictive view, we conducted a qualitative study to explore how French multinational banks respond to LOF challenges in India, an adverse institutional environment typical of emerging markets but also a unique setting due to strong economic nationalism and cultural traditions. This study (1) identifies legitimation strategies other than the known passive or reactive ones and (2) allows us to extend the existing institutional 
theoretical framework by uncovering (a) the organisational practices that operationalise the legitimation strategies and (b) the resources that are used to implement these practices.

\subsection{Research Context: The Banking Industry in India}

Following the well-documented single-country multiple case study methodology (Yin 2014), this study depicts the core internationalisation strategic decisions of foreign banks in India. Following economic liberalisation from the late 1980s onwards, the Indian banking sector is today typical of a transitional economy (Mian 2006), in which public banks account for $72 \%$ of the market (asset ratio in 2015), old private sector banks for about $5 \%$, new private sector banks for $16 \%$, and foreign banks for approximately $7 \%$ of market share. Many public banks are heavily indebted due to bad loan policies, state interference, and, more generally, poor organisational performance. Old private sector banks broadly share similar features and are slowly disappearing from the Indian banking landscape. New private sector banks have modern technological management features with standards similar to those of their Western counterparts. More than 40 foreign MNBs are present in India, mostly Anglo-Saxon (e.g., Standard \& Chartered, HSBC, CitiBank, Barclays), along with a few other nationalities (e.g., Deutsche Bank, DBS, BNP Paribas) in terms of assets, activities, and branches.

Despite differences in their historical presence and size, MNBs share a few characteristics. First, they are all embedded in the same institutional and regulatory framework and, although some of them have well-diversified activities across the banking spectrum (retail, commercial, and investment), the majority focus on commercial banking activities. Second, they all have wholly owned operations with a limited number of partnerships with local firms in specific niche areas (e.g., life insurance, home finance). The Indian central bank (i.e., the Reserve Bank of India $[\mathrm{RBI}])$ has been wary of foreign entities and has prevented them from achieving strong positions in the country, by granting licences to operate piecemeal while placing punctilious requirements on them (e.g., requiring daily reporting procedures). For a foreign MNB, it remains difficult to fulfil these requirements, which has led to high administrative pressure and a limited survival rate. Many foreign banks have in fact given up their banking licence in India. Even though the Indian market has high potential, relatively few companies have been able to grow significantly in the country in general and even fewer in the banking industry: Between 1999 and 2009, the ratio of foreign banks' assets to total assets in India has remained stagnant at $6 \%$ (Claessens and van Horen 2012).

Sheth (2011) states that emerging economies tend to strongly influence sociopolitical institutions in the form of religion, state interference, NGOs, and local communities, and India is no exception: The embeddedness of business networks and activities within certain traditional social communities has survived economic liberalisation through interlocking directorships and human resource management practices (Chen et al. 2015; Lachaier and Clementin-Ojha 2008; Naudet and Dubost 2016). In this respect, it is a prerequisite for foreign companies to embed themselves into local business networks to reach customers. 


\subsection{Research Methodology: A Single-Country Multiple Case Study}

Our single-country multiple case study methodology allows us to accommodate the aforementioned research context and focus on understanding the dynamics present within single settings (Eisenhardt 1989). Thereby, it enables us to better grasp phenomena that are deeply embedded in their context (Yin 2014).

The three French foreign bank subsidiaries present in India represent the sample units. Overall, data stem from representatives of, or experts on, foreign bank subsidiaries in India; the qualitative information these people provide relates to organisational practices directed at external recipients (legitimation strategies) as well as intraorganisational means to implement these strategies (internal implications).

The three banks operate similarly and in comparable segments, and their history is somewhat analogous, if not intertwined. Because they are French, the banks under study have higher LOF levels than English and colonial-related banks, which may have accumulated more experience and political connections over time (for more details on the sample units, refer to Table 1). We determined that the cases are typical (Yin 2014), displaying activity that reflects how foreign banks usually operate in India, rather than extreme (e.g., that of British banks benefitting from postcolonial ties, that of new entrants such as the Emirati bank). In particular, French banks are typical non-Anglo-Saxon foreign banks in India, and the period of the research (between 2014 and 2016, long after the 2008 crisis and its immediate consequences) is also ordinary, which helps strengthen the external validity of the study.

The unit of analysis is the organisational practices of French MNBs' Indian subsidiaries in the local environment as well as inside the organisation. To help us focus on the micro level of the organisation, data include primary information from indepth interviews (IDIs) with country managers and senior position-related bankers within the subsidiary or at the headquarters: three IDIs with a country manager (French bank 1), one IDI with a country manager and three interviews with managers based at headquarters who work in the risk management division (French bank 2 ), and one IDI with a country manager (French bank 3). Because we interviewed six French participants more than once, a total of ten interviews emerged. We conducted interviews in English or French, sometimes in Hindi (for certain Indian managers), and they lasted one to one and a half hours. The interview guide consisted of semistructured questions pertaining to three major subtopics relating to legitimation strategies implemented in the Indian sociopolitical ecosystem relevant to foreign banks and to their internal consequences (see Appendix 1 for the interview guide): (1) subsidiary interactions with local sociopolitical actors (i.e., regulators and government agencies, media, civil society organisation, local competitors, and local customers); (2) subsidiary initiatives to reach out to sociopolitical actors; (3) subsidiary interactions with headquarters with regard to negotiating the local strategy. Interviews were not recorded, as many respondents were worried about data confidentiality and noted that they needed to obtain headquarters' authorisation.

To increase external and internal validity, we conducted source, data, ecological, and methodological triangulation (Denzin 1978). The following subsections describe each in more detail. 


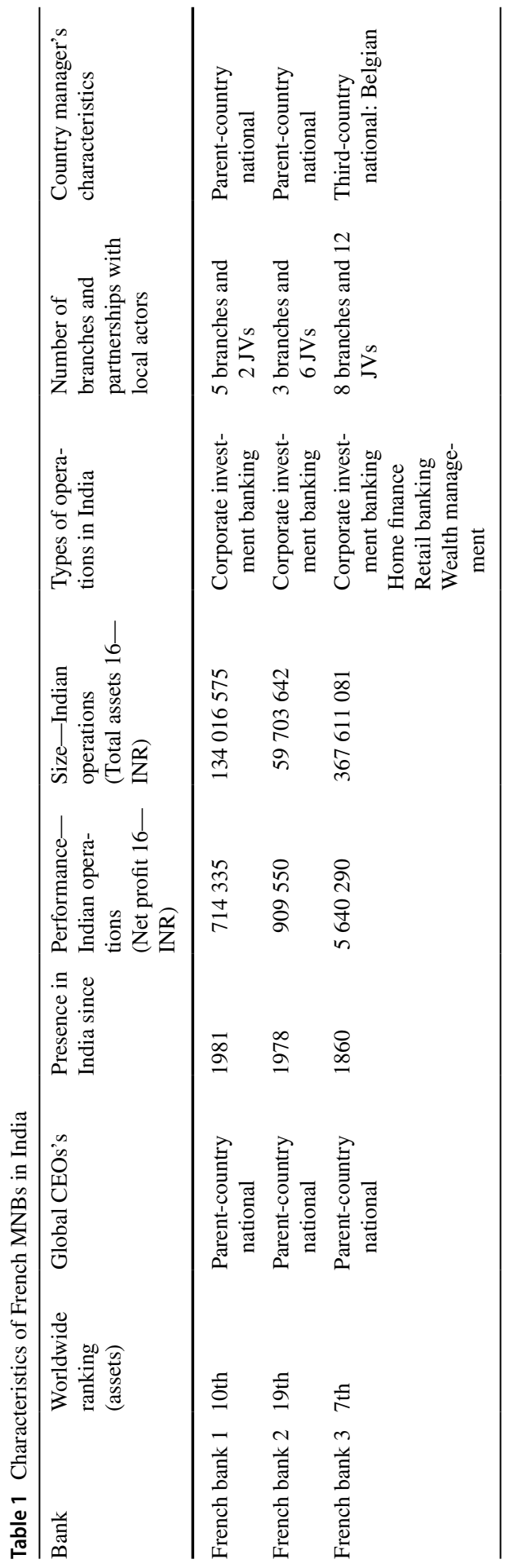




\subsubsection{Source Triangulation}

Due to confidentiality and response biases inherent to the banking sector, we complemented the set of primary data from French banks with interviews with other actors in the foreign banking sector (see Table 2): Overall, we interviewed five country managers from non-French foreign banks (eight interviews in total: three German banks, one Singaporean bank, one United Arab Emirates bank, two South African banks, and one Canadian bank); one financial analyst working for the largest Indian private equity firm; three journalists (two Indian journalists, including one banking and finance editor of a leading daily journal and one French journalist based in India for 10 years); one public relations agency officer and one consultant specialising in foreign banks in Asia; and five corporate employees whose companies are clients of French banks (nonbanking foreign subsidiary CEOs and Indian Business Groups' top managers). For non-French foreign banks, the interview guide follows a similar structure. For nonbanking foreign subsidiary CEOs, we also included questions regarding their perception of domestic and foreign banks. For interviews with journalists, we asked a general question regarding the gap between domestic and foreign banks and the perception of foreign banks. This second set of interviews enabled us to collect two types of additional primary data regarding (1) foreign banks in general and their interactions with local sociopolitical actors and (2) French banks. We did so to triangulate and complement data given by French bank subsidiary CEOs, who were sometimes not willing to disclose what they perceived as sensitive information.

\subsubsection{Data Triangulation}

To not only minimise selection bias but also confirm primary data provided by directors of Indian French banks' subsidiaries and other directors from other foreign banks, we complemented the primary data with secondary data collection aimed at documenting the characteristics of Indian economy and regulations applied to foreign banks, as well as information about the banks under scrutiny (historical data about the banks in India, organisational charts, performance, and biography of directors). These secondary data fell into two categories (Yin 2014):

Table 2 Triangulation of primary data sources

\begin{tabular}{lcl}
\hline Interviewee profiles & $\begin{array}{l}\text { Number of people inter- } \\
\text { viewed }\end{array}$ & $\begin{array}{l}\text { Number of in-depth inter- } \\
\text { views (several per inter- } \\
\text { viewee) }\end{array}$ \\
\hline Bankers & 11 & 18 \\
Financial analyst & 1 & 1 \\
Press journalists & 3 & 3 \\
PR agency and consultants & 2 & 3 \\
Bank corporate customers & 5 & 7 \\
Total & 22 & 32 \\
\hline
\end{tabular}


1. Documentation, which covers the following: all documents in open access and internal to the banks that interviewees provided during the interviews, collected from September 2015 to July 2017 (financial and annual reports, CSR reports; public relations documents, documentation about the history of the banks [e.g. French Bank 3's booklet published on the occasion of its 100-year anniversary]); academic documents emanating from international institutions and academic conferences and seminars about the Indian economy, politics, and the banking sector; nonacademic documents related to the Indian economy, politics, and the banking sector from consulting firms and the press identified in Factiva data base (local press such as the Economic Times, Business Line, Indian Express, Hindustan Times, Front Line, and international press such as Le Monde, Financial Times, and The Economist); and documents about foreign and Indian banks collected from RBI's database (bank assets, deposits, performances, number of branches, amount of local capital, and loan default rates).

2. Archives: We accessed the archive centres of French bank 1 (two sessions of $4 \mathrm{~h}$ each) and French bank 2 (one session of $4 \mathrm{~h}$ ), which contained information about the international expansion of the banks, the international motivations and obstacles, and the activity of their Indian subsidiary (i.e., notes, correspondence, pictures, organisational charts, quantitative data, internal reports about the Indian political, economic and legal situation, and historical data).

\subsubsection{Ecological Triangulation}

Most interviewees were reluctant to be recorded; therefore, we took manual notes and later transcribed them. We submitted these notes to the respondents for reliability checks, and we included their modifications in our data.

\subsubsection{Methodological (Tool) Triangulation}

In addition to primary data collection, we added secondary data such as press articles (extracted from Factiva search and a daily press review), annual reports, financials, archived documents retrieved at headquarters archive centres, and website content analyses. This rich set of data provided insights into the regulatory environment, MNBs' performance in India and key stakeholders in the banking industry and within each MNB. Crossing primary and secondary data allowed us to obtain a more comprehensive and accurate picture of how foreign banks develop their presence in India.

To analyse the total set of secondary and primary data combined, we first used a thematic analytical strategy guided by extant theory (Eisenhardt 1989), especially Li et al. (2016), who suggest that legitimation strategies are grounded in a relational process engaging several actors simultaneously (the ecosystem of the subsidiary composed of the legitimacy providers located in the host and organisational environments). We retained two analytical themes: (1) legitimation strategies that emerge through organisational practices supporting interactions with local sociopolitical legitimacy providers (e.g., government agencies and regulators, media and civil society, local competitors, local customers) and (2) internal organisational 
implications in the form of intraorganisational practices supporting legitimationseeking interactions with internal actors.

Second, we analysed the data using a 'cross-case pattern' perspective (Eisenhardt 1989), through which we identified similarities and differences between the three French banks. As Eisenhardt and Graebner (2007, p. 30) suggest, "case researchers need to escape the 'idiosyncratic detail' of individual cases and conclude with only the relationships that are replicated across most or all of the cases". We therefore only report the results of cross-case patterns that emerged from our familiarity with the whole set of data, which we progressively organised on the basis of within-group similarities (the three French banks), coupled with within-group and intergroup differences (the three French banks compared with each other as well as other foreign banks).

\section{Empirical Findings on Legitimation Strategies: Rhetoric Strategies Beyond Isomorphism, Transference, and Political Activism}

\subsection{Isomorphism to Local Institutional Conditions: Interactions with the Regulator}

Most of the institutional work is carried out daily with the banking regulator-the RBI (Indian central bank). Given the centrality of the regulator, MNBs respond to legal duties and interact with it through organisational practices observable at the level of the organisation (conformity to the regulator's requirements and collective lobbying) and country managers' personal relations with the regulator. For the regulator to grant a licence or any specific favour, foreign banks must justify why they are in India and how they are contributing to the Indian economy: "It's true that we have to prove our raison d'être" (French bank 3 CEO). Similarly, "We put up billions of dollars on the table" (this firm had acquired the Royal Bank of Scotland's Indian corporate asset portfolio). "This is a strong commitment with respect to the RBI" (Emirati bank CEO). In addition to pressuring foreign banks for commitment, the regulator has also proved to be quite bureaucratic in its relationships with MNBs: "The regulator is very punctilious and intrusive. It is difficult to meet its requirements" (French bank $1 \mathrm{CEO);} \mathrm{"Although} \mathrm{the} \mathrm{regulator} \mathrm{carries} \mathrm{out} \mathrm{an}$ overall audit only once per year, we (i.e., our bank) receive letters from him every week requesting some information" (French bank $1 \mathrm{CEO}$ ). In contrast, other foreign banks' CEOs stated that the regulator was rather accessible: "When it comes to representing the bank's activities in India, we can say that the regulator is very approachable - no need for any intermediary to talk to the regulator" (Singaporean bank CEO); "We talk to the regulator, try to understand what [he] wants. The regulator is very approachable" (Canadian bank CEO). However, French bank 3 CEO noticed that since September 2016, when a new RBI governor was nominated, "It has become impossible to meet the RBI, [and] embassies say the same thing. The RBI governor is inaccessible and very silent. We miss the former governor."

Therefore, country managers have tried to engage in interactions with the regulator: "In addition to office work, there is also an institutional representation work: 
French and European institutions in India [...]. French bank CEOs meet very regularly, less often than with other European banks. It's mostly the case at European Business Group meetings: We produce a yearly brief for the public authorities. It's like lobbying regulatory institutions" (French bank CEO 1). One key issue for foreign MNBs in India relates to their collective organisation: "Foreign banks are institutionally very poorly organised: There is no professional association. There is the IBA [i.e., Indian Banks Association] but the agenda of the IBA is very domestic. Large Anglo-Saxon foreign banks do not need professional associations; they already have their own institutional channels and want to protect this advantage vis-à-vis other foreign banks. They do not need any sectorial organisation" (French bank 3 CEO). All MNB country managers agreed on the need to approach the regulator routinely. Complying with demands is central to this process; thus, we consider it isomorphic from a coercive point of view. Although MNBs in India spend significant resources developing relations with the regulator, the lack of institutional rooting and the inability to organise collective actions remain essential challenges. Indeed, several foreign MNBs have recently withdrawn from the Indian market (e.g., the Commonwealth Bank of Australia in 2016). However, French MNB subsidiaries-despite complaints regarding the high level of bureaucratic management-have been able to meet the regulator's requirements.

\subsection{Transference: Interactions with Local Partners}

Although French MNBs typically operate through wholly owned subsidiaries in India, the MNBs studied herein have established partnerships with small local actors in niche banking segments, including life insurance, securities services, and home finance. These joint ventures operate independently and are thus loosely coordinated: "We also have Amundi, a [joint venture] with State Bank of India, which is another subsidiary of our group. We have regular exchanges with Amundi but no common business" (French bank $1 \mathrm{CEO}$ ); "We acquired Sharekhan [a digital retail broker], which is a further step towards developing our non-wholesale and nonbanking franchise in India" (French bank 3 CEO). These partnerships help French banks justify their commitment to India to the regulator through know-how transfers and gain local knowledge and contacts.

To a more limited extent, the three French MNBs have all partnered to address the specific needs of local financial actors (e.g., in-home finance, retail banking). These partnerships are peripheral to the subsidiary's core business, but they nevertheless allow entry into potentially promising future markets. Through transference strategies, they have all designed an organisational structure benefitting from local partners' local knowledge and legitimacy, while demonstrating to the regulator a commitment to transferring know-how to local actors.

\subsection{Political Activism: Interactions Between Governments}

Interactions at the highest political level remain elusive for the French MNBs, even though core decisions regarding entry into the Indian market, along with the number 
of branches across the territory (i.e., distribution), mostly lie within the host government. The following statement illustrates how crucial political relationships are in this industry: "If your government has a good relationship with the government of India, banks are more successful. This is just a point to keep in mind" (Singaporean Bank CEO). Intergovernmental relations represent the backbone of international banking development, consistent with the national sovereignty characteristics of the banking industry.

To enter the market, foreign banks must obtain a banking license, which requires a long process that has more to do with political than business negotiations. Throughout this process, regulators tend to adopt a conservative approach to prevent foreign banks from gaining too large an access to the Indian market, so that they ensure that they meet World Trade Organisation obligations, as stated by Shaji Vikraman, in the daily The India Express: "The power to grant licences to banks, both domestic and foreign, lay with the central bank and were laid out in the RBI Act. But to determine the number of branches for foreign banks in India, and to ensure compliance with international rules like those specified by the World Trade Organisation, the Ministries of Finance and Commerce too were involved" (Licensing foreign banks: RBI's caution and a hard lesson, April 5, 2017). More precisely, a committee composed of central bank and government representatives makes the decision regarding the number of branches to be granted to the foreign bank: "The proposals of foreign banks intending to start their Indian operations, either through branch operations or representative offices, are vetted by a high-powered committee which includes representatives from the home ministry, finance ministry, Reserve Bank of India and intelligence agencies."

Archive documents from French bank 2 reveal that the license acquisition process depends considerably on intergovernmental relationships. French banks 1 and 2 sought a licence to operate in India at around the same period (beginning in the 1980s). A French bank 2 internal note states: "The decision between several samecountry candidates is based on: the applicant's international standing reputation and pre-existing activities developed in India ... [and] the anteriority of the licence request, conditioned by recommendations formulated by home country authorities". The latter aspect highlights the importance of French authorities in shaping the decision regarding the banking licence. In this particular case, it is interesting to note that there was a conflict between the French authorities and the Indian Ministry of External Affairs on one side and the Ministry of Finance on the other, the former privileging French bank 1 and the latter French bank 2. Despite an audience with Prime Minister Indira Gandhi, the decision was shaped in favour of French bank 1.

Moreover, political interactions do not cease even after the foreign bank has entered the market. French bank 3 CEO related how the Indian subsidiary has been at the centre of a political negotiation by connecting its clients with the Indian Minister of Finance: "The Indian Minister of Finance was in Paris for an [Organisation for Economic Co-Operation and Development] meeting and went to Roland-Garros [a tennis tournament]. I got a phone call from one of my Indian clients asking if it was possible to get tickets with the Indian Minister of Finance. It was very easy for me to get the tickets through the headquarters. We were the three of us at the tennis match, I left them at some points: they discussed a lot as they had things to tell each 
other. The goal was to see each other outside India." This example illustrates that French bank subsidiaries in India, however small, are connected to key politicians and even establish a bridge between the corporate and the political worlds. They maintain corporate institutional relations with the support-when needed-of the headquarters. The case of India is particularly revealing, as the current political climate may not allow corporate employees to meet the government and discuss issues openly. Only outside the country can they talk freely.

To gain access to the Indian market, MNBs have established relationships with host and home governments. As a WTO member, India is required to open its market to foreign MNBs, and yet this process is carefully monitored by both governments. French MNBs must spend a considerable amount of time lobbying for their entry to both governments in competition with their peers. However, these political interactions do not cease following their entry into the local market. Country managers reveal that they maintain a high level of political interactions at the crossroads between corporate clients and the government. The case of India is particularly revealing, as the current political climate does not allow business groups to discuss issues openly with the government inside the country. Such discussions can happen abroad, notably with the help of foreign MNBs, which often represent the overseas institutional and financial support of such business groups. Thus, French MNBs use political tools (home-host diplomatic relations and corporate institutional relations through the appointment of intermediaries) to secure a good relationship with the host government, which is less conservative than the regulator.

The political activism legitimation strategy involves the appointment of intermediaries, especially for French bank 2. Following an initial setback, described previously, French bank 2 continued to lobby the Indian government taking a different route, as stated in an internal note: "We've just met with some 'middlemen' to get the licence: $\mathrm{Z}$ - who is close to Indira Gandhi [...] and $\mathrm{S}$ - met at the Duke and the Duchesse de la Rochefoucault". In another internal note, French bank 2 also recruited "two advisors to facilitate our licence application: Mr. M-whose name should not appear as he is a 'member of the family', and Mr. G- $[\ldots]$ funded on our entertainment budget [...]. We need to hide the payment source, especially his treatment and flight tickets". French bank 2 obtained the licence in 1984 at a time when Indo-French relationships were deepening significantly.

\subsection{Rhetoric Legitimation: Interactions with Local Clients, the Civil Society, and the Media}

We observe that political lobbying and regulatory compliance interactions are not sufficient to grow business; ultimately, the subsidiary's survival depends on its capacity to attract local customers, which defines its local commercial performance. From this perspective, rhetoric strategies of legitimation aim at diffusing a positive image of the organisation and give a prominent role to communication to, and public relations with, key legitimacy providers. Our results suggest that rhetoric processes target three recipients: local customers (and indirectly local competitors), the civil society, and, to a lesser extent, the media. 
We start with the marketing perspective and first present interactions with local customers. In terms of relationships with clients, rhetoric strategies tend to be supported by three categories of practices: a specialization offering strategy carefully communicated to the market, an ethical reputation in brand management heavily emphasized in the communication with clients, and the management of customer relationships adapted to the Indian culture. The first two heavily rely on the transference of a global expertise and ethical reputation from the headquarters to the subsidiary. The third relies on effective cultural sensitivity of the organisation concerning the host environment.

Looking in detail at the three categories of practices used in rhetoric strategy, we first note that French MNBs tend to specialise in a set of corporate activities based on exclusive competences that local banks do not possess, and they carve out market niches where they can enjoy monopolistic positions. French bank 3 CEO says: "We bring funding to the Indian economy where Indian banks cannot go" (e.g., they engage in international operations, especially those involving MNBs' home markets, offering services such as foreign exchange and access to capital markets). They also accompany Indian firms abroad by providing a range of services (e.g., tax payments, salary treatments, customs guarantees). No Indian bank has the capacity to follow its customers in Europe, and similarly, no French bank has the capacity to follow an Indian company in the United States (this business accrues to American banks): "If an Indian company wants to take over a firm in Europe, there will be no Indian bank to support it in Europe; therefore, the company has to rely on a bank present in Europe. [...] More generally, each bank has geographical specificity; no bank can cover the whole world" (French bank $3 \mathrm{CEO}$ ).

We found that MNBs communicate about their superior expertise in designing complex products according to customers' requirements and/or a specific sector: "There are many areas where Indian banks do not master the expertise, for instance in personal finance derivatives" (French bank 3 CEO); "There is a knowledge and technical expertise gap with Indian banks, who lag behind foreign banks by far in this respect" (French bank 1 CEO). In a similar vein, French MNBs have developed expertise in certain specific sectors (e.g., French Bank 1 is a worldwide leader in aviation financing) and hold certain clear advantages over other MNBs: "French banks are known to be good at structuring and in project finance" (German bank $\mathrm{CEO}$ ), so that they can make use of this expertise rhetorically. French MNBs, as with many other MNBs (at least in India), are known for their high levels of service. Being a client of a foreign bank allows one to enjoy higher service quality, which Indian banks cannot provide currently (though some local banks, especially in the new private sector, are catching up quickly). For French bank CEO 3, "Banking business requires a high level of trust and a significant knowledge: We have [had] relations with Volkswagen for a very long time, for instance, not General Motors. Indian banks can't do business with European companies as their level of knowledge is not enough."

Second, rhetoric strategies used in the marketing context are based on MNBs setting up compliance departments in charge of internal control ("The internal police", German bank CEO). When it comes to complying with world-class ethical 
standards, French MNBs retain a high reputation as well as governance advantage over local competitors:

"Our bank is known to be risk-averse, meticulous and to ask for many documents in order to mitigate potential risks to clients. When I was posted in Africa, our clients used to tell me that we were annoying. Yes, we are annoying, that's true, but thanks to our meticulousness, for instance, we do not have any outstanding debts in the oil sector, where we are very much involved although prices are very low" (French bank $2 \mathrm{CEO}$ ).

"There have been significant issues around the Tata Mundra project [a large power plant project]. When contracting with Tata, we introduced a series of clauses, and today Tata is paying us, unlike Indian banks that need now to restructure their loans. We have a better risk assessment" (French bank 3 CEO).

However, a German bank CEO contradicted this view: "Japanese banks are very good in compliance, while French banks are lagging a little behind."

These high ethical behaviour and reputation standards translate into awards that are displayed on websites and in corporate booklets. French bank 1, for instance, was nominated by the magazine The Banker as 'Bank of the year 2007' for its social and environment responsibility, and it is today the world leader in green bonds. Similarly, Fortune magazine ranked French bank 3 the sixth in the world in its World's Most Admired Companies list; it was also nominated as 'Best Bank of the Year 2008' by The Banker magazine. French bank 2 received, in 2015, an Indian award for the best branding amongst small banks.

Finally, since the media and other civil society organisations are more likely to investigate MNBs at home and in respective host markets, these MNBs have developed strong ethical policies to cope with any negative reputation risk to their brand: "When appointing a French expatriate at the head of the subsidiary, this reinforces a discourse of governance under control and allows [us] to avoid the risk of certain practices such as corruption" (French Bank 1). Similarly, French bank 1 CEO put forward this specific action: "We stopped financing coalmine projects as well as coal-based power plants." The three French banks also withdrew their participation in a mining project developed by an Indian business group in Australia, due to its proximity to a coral reef.

Third, rhetoric strategies used in the marketing context relate a customer relationships management style adapted to the Indian culture. Respondents made it clear that business with local customers is contracted between Indians (French bank 1 CEO: "Indians do business with Indians"). Therefore, those at the negotiation table are exclusively Indians. More precisely, all the MNBs studied herein resort to a similar coverage model: Below the CEO, a few senior bankers are in charge of a portfolio of personal contacts with top corporate managers in a specific industry, and it is their job to gain appointments with them. This coverage work is filled by Indian nationals, as they are deemed more knowledgeable about local business networks and negotiation practices. They can rely on customers viewing them as part of their in-group despite the foreignness of the organisation for which they work. Once a deal is potentially confirmed, the senior banker contacts the corporate investment banking team and asks for the right product expertise to suit the needs of local customers-for instance, in terms of loan instalment conditions. 
Beyond the customer, the second category of recipients of rhetoric legitimation strategy is the Indian civil society. Firms must show strong compliance with the country's cultural and religious traditions. French banks' subsidiaries grow in the respect of Indian traditions and display the desire to be perceived as natives. For example, the book about the history of French bank 3 in India [The History of (French bank 3) in India, 1860-2010 (2010), 115p] describes the local rituals mobilized when a branch is opened: A Hindu prayer (Pooja) is executed following religious Hindu protocols, followed by the distribution of Indian confectionaries (laddoos) to employees. Another special Hindu prayer is used when antivirus software is installed on each computer, and afterwards, the computers receive a tikka (red religious mark affixed on the 'forehead' of computers).

French bank 2 also sponsors sports initiatives in India, and French bank 1 organizes internal auctions benefitting NGOs and educational institutions. French bank 3, which has developed a vast CSR program that covers various domains, organized an exhibition on the theme 'Women Changing India' to celebrate the subsidiary's 150 years in India. The country manager of French bank 2 noted, "Responsibility is created everyday with clients. [...] For example, our bank decided to step back from the coal sector. Responsibility in terms of addressing climate change is important for companies today, including banks." More generally, MNBs also conduct a certain number of CSR activities in line with legal obligations: "We conduct CSR actions, but we do not go through a CSR agency. We have developed internal programmes managed by the HR department" (French bank 1). These initiatives are highlighted in the press and promoted on their website to reach civil society, customers, and the regulator. Indian nationals handle communication and public relations efforts in close collaboration with the headquarters and the country manager.

Finally, a third category of recipients of rhetoric strategies consists of the media. However, an interview with the economic editor of a leading economic daily reveals that the French MNBs in our study do not interact with local press to a great extent: "Reputation is something you've got to work on. For example, Citibank approaches journalists quite often. They meet the press regularly and they talk. British and US banks in general talk. European banks are quieter, which, as long as they face no problem, is fine. The day they are in trouble, the situation can very quickly worsen." More than a possible country-of-origin effect, this reticence is attributable to the personality of the CEO, as a South African bank's CEO mentions: "I like to talk. I often speak to the media. Also, it helps build the brand."

\section{Empirical Findings on Internal Implications Emerging From Legitimation Strategies}

Legitimation strategies involve organisational practices that reflect a shift in the locus of control from the headquarters to the subsidiary. This necessarily leads to the emergence of tensions between the subsidiary's local development strategy, which requires effectiveness, and the headquarters' demands for efficiency and control. We next summarize the organisational practices mobilised to mitigate these potential tensions between the headquarters and the subsidiaries. 


\subsection{Managing Central-Local Tension When Designing Product Offerings}

International banks are structured around a product/country matrix structure with the aim of reconciling the tension between the headquarters and the subsidiary. Senior bankers are responsible for coverage activities designed to develop and manage strategic relationships with large corporate clients. All French MNBs have set up marketing coverage teams inside their Indian subsidiaries based in Mumbai. Yet, the corporate investment banking division providing the technical expertise is based at the headquarters located in the regional hub (either Hong Kong or Singapore, or both). Therefore, subsidiaries simultaneously build close relationships with local customers and within the bank. However, within foreign MNBs, French banks have kept a specific model of highly centralised control alongside the matrix structure, which gives the local subsidiary very little room to manoeuvre: "There are three levels of procedures: the headquarters, the business line or the region, and finally the country. I can implement an Indian strategy only if it does not clash with the headquarters' strategy or that of the business line. This is quite centralizing" (French bank 3's CEO).

In addition, the country risk division helps mitigate the tension between headquarters and subsidiary. Regularly, their teams visit to evaluate the risks associated with the country. French bank 2's head of country risk division notes: "There is a conflict of interest problem: Risks need to be independent from business. The risk division is neither contingent to the subsidiary's revenues nor to the headquarters'. When we visit foreign countries, there is always a possibility to be coaxed by the subsidiary CEO." We note that the conflict between risks assessed at the headquarters and opportunities developed at the subsidiary level can be subject to negotiations when the country risk division visits the country. However, it may sometimes happen that the country risk division remains inflexible, as stated by French bank CEO 3: "Hinduja was a very problematic Indian business group 20 years ago, bogged down in corruption scandals. The headquarters forbade us to do business with Hinduja. Today, we are still forbidden from doing business with Hinduja [although] the group is much more operational now. This is the role of the risk division." Thus, the subsidiary must comply with internal rules in terms of client choice when it becomes a touchy subject.

\subsection{Managing Central-Local Tensions When Addressing Cultural Identities}

Managing cultural identities (national as well as corporate) is a central domain in which MNBs must make decisions to mitigate tensions between the central and local perspectives. On the one hand, MNBs must ensure strong corporate governance to avoid becoming too local; on the other hand, they must comply with local human resource management practices that cannot be changed because they reflect enduring cultural traditions or because it is more advantageous to keep them local.

The promotion of headquarters' identity to ensure strong corporate governance can be observed in decisions about staffing the head of the subsidiary. Because country managers oversee formulating the strategy of the local subsidiary in line with the group's global strategy, they have a critical role: "The CEO is both the first 
banker of the subsidiary and a representative. As a representative, the CEO has two roles: representing the bank's activities in India and at the global level, protecting Indian activities within the bank's management board" (Singaporean bank CEO); "A CEO has to both establish relations with clients and with institutions. This also depends on the character of the person. Some like to be in touch with the clients, for instance" (French bank CEO 2). When appointing the subsidiary country head, French banks show contrasts with other banks: "Only two types of banks have expats in their Indian entity: the French banks and the Japanese ones" (Canadian bank CEO). Other MNBs have all appointed an Indian national (i.e., a host-country national) at the helm of the Indian unit.

Interviewees expressed three arguments behind the choice of appointing a parentcountry national over a host-country national: aligning local working culture and global strategy, enhancing subsidiary governance, and overcoming linguistic barriers with headquarters. First, when appointing parent-country nationals, the bank nominates an executive from the headquarters who will assume a representation role amongst the various institutional agencies and ensure alignment between local and global strategy. The parent-country national will bridge cultural differences between headquarters and the local unit: "An expat at the head of the subsidiary eases the work of the senior bankers by improving communication flow with the risk department, establishing a link with the group's strategy, and bridging the gap between Indian and French working culture" (French bank 1 CEO). Second, French MNBs nominate French nationals as country managers (with a rotation system: every few years, country managers are required to move as part of a preestablished high talent career path), with a view to monitor subsidiary governance better and avoid becoming too local, especially in countries with high levels of corruption such as India: "French banks are rather cautious on this issue. Appointing an expat as the subsidiary head strengthens the idea that governance is under control and mitigates risks related to certain practices such as corruption" (French bank 1 CEO). However, the Singapore bank CEO expresses a different view: "We do not have a colonial mindset, like sending a French person to represent the French bank in India”, and similarly the German bank CEO noted: "French banks 2 and 3 are very Franco-French [...], managed by expats."

Third, the linguistic barrier with the headquarters must be addressed to connect with the corporate culture. For the United Arab Emirates bank CEO who previously worked with French bank 1, the CEO staffing policy also depends on the medium of communication within the organisation: "Having a local at the head helps the organisation in the foreign environment, but a local has to be able to integrate the Indian unit within the group. You need the support of the headquarters. You need to speak French in this respect. When I was working with [French bank 1], I needed to learn French. I asked the bank to let me spend some time in France, and when I came back, I had learned a little bit of French. French banks are maybe less global in terms of communication but not in terms of business thinking: they are very global in this respect."

Finally, country managers do not have much control over their senior bankers: "Senior bankers are evaluated by the headquarters [...]. The country head has no decision-making capacity over the salary or the bonus of senior bankers. It is the top 
manager in Paris. A good country head is one who has established good relations with top managers based out at the headquarters and who is then able to influence his/her senior bankers in the subsidiary" (French bank 2 headquarters top manager). Managing a subsidiary is essentially a relational occupation. Being able to influence headquarters-based top managers is a key success factor in subsidiary coordination.

If MNBs ensure the transfer of headquarters' identity and original corporate culture, they also tend to integrate local identities that would be difficult to change when managing Indian employees and therefore adapt the headquarters' organisational practices. For instance, French MNBs have retained titles such as 'Managing Director' and 'Senior Banker' and have implemented a seniority-based motivation system (French bank $1 \mathrm{CEO):} \mathrm{"This} \mathrm{is} \mathrm{a} \mathrm{rank} \mathrm{that} \mathrm{reveals} \mathrm{seniority.} \mathrm{Within} \mathrm{French} \mathrm{banks,}$ this denomination has been removed, because what matters for us isn't seniority but the importance of the job and the employee's skills. In India, the structure is pyramidal and very hierarchical-seniority-based denomination remains." This adaptation of human resource management tools also targets the central issue of how to keep Indian employees and avoid poaching by Indian private banks. Thus, foreign banks do not specifically try to compete in terms of salary but rather in terms of modern management styles that are attractive in a traditionally conservative Indian culture exposed to new management practices brought by foreigners (French bank 1 CEO: "Indian companies are characterised by a very pyramidal structure, while foreign banks, especially Western [ones], have flatter [structures]"). Moreover, some Indian managers pursue an international career, which helps increase awareness about India at the headquarters: "At [French bank 3 Asia], there are many Indians who quite logically understand India better. This helps reduce tensions. And also, there has been the exchange with Britain, which considerably reduces the cultural gap, unlike in Japan or Korea. My local management committee is very Anglo-Saxonised."

However, this adaptation of headquarters practices can also reflect the desire to take advantage of local practices viewed as a prerequisite of commercial performance of the subsidiary or even avoid the risk of being rejected because of cultural nonnegotiable issues from the Indian perspective. Local employees, especially managers working in coverage activities, are the actors who make a link between the organisation and the local environment by bringing their portfolio of contacts. In India, business is done amongst Indians in terms of winning deals and managing customer relationships. "This is something one should clearly keep in mind: Indians do business with Indians" (French bank $1 \mathrm{CEO);} \mathrm{"Business} \mathrm{is} \mathrm{contracted} \mathrm{amongst}$ local people. This is the senior banker's job: they know very well the corporate sector and belong to the same networks [...]. These people often belong to the Marwari community [an influential business community in the banking sector]; they are cousins or have cousins in common, and they meet at wedding events" (French bank 2 CEO). Avoiding relying on such traditional in-group identities that define ways of doing business in India would not only be ethnocentric, it would also compromise the subsidiary's local performance. 


\section{Discussion}

Using the institutional framework complemented with the resource-based view on strategic implementation, our results suggest that MNBs in India use a combination of legitimation strategies targeted at external recipients based on specific organisational practices and that these strategies are enabled through specific resources from the headquarters that require subsidiaries to balance global/local tensions.

\subsection{Gaining Local Sociopolitical Actors' Acceptance Requires a Combination of Legitimation Strategies}

Our results suggest that designing legitimation strategies in high LOF countries is based on a combination of four approaches: two more passive (isomorphism and transference), one reactive (political activism), and one proactive (rhetoric). Each of these strategies has specific objectives and is implemented through specific organisational practices and supporting resources that overall contribute to gaining the licence to operate in India despite the negative impact of LOF (see Fig. 1; the numbers 1-3 are consistent with the contributions listed in the Introduction). This micro level of organisational practices is useful to draw a concrete picture of what MNBs (can) actually do to generate and organisationally implement legitimacy. Put differently, by breaking down the host environment into various actors, we are able to shed light on the legitimation processes at play in the day-to-day management of a banking subsidiary. Legitimacy must be crafted daily, the result of which needs to be appreciated at the level of the sociopolitical actor in question. This perspective implicitly advocates placing more power in the hands of the subsidiary in response to the call for more agency in institutional theory (Kostova et al. 2008); rather than passively enduring the local environment, subsidiaries should engage proactively in interactions through specific organisational practices to gain legitimacy and increase their local presence. It also calls for more attention to the headquarters-subsidiary relationships as a source of MNEs performance and competitive advantage (Kostova 1998).

Our results also suggest that MNB subsidiaries must take into account both external (i.e., government, regulators, society-level actors, and customers) and internal actors (i.e., local employees and country managers of the subsidiary and headquarters-level actors of the group), as organisational practices are oriented towards external actors but are internally established. They provide a link between micro interactions occurring at the subsidiary level and broader macro processes of legitimation occurring at the level of the intraorganisational network (the group) and the external level (the country).

We also note that legitimation strategies are not independent. For instance, human resources management actions (e.g., appointing country managers, senior bankers and other local employees) are both 'substance' tools that respond to isomorphic pressures and 'form' tools that create a global (central)/local discourse regarding the subsidiary's identity. Furthermore, legitimation strategies are not exclusive but complementary, as country managers make use of more than one type of legitimation 


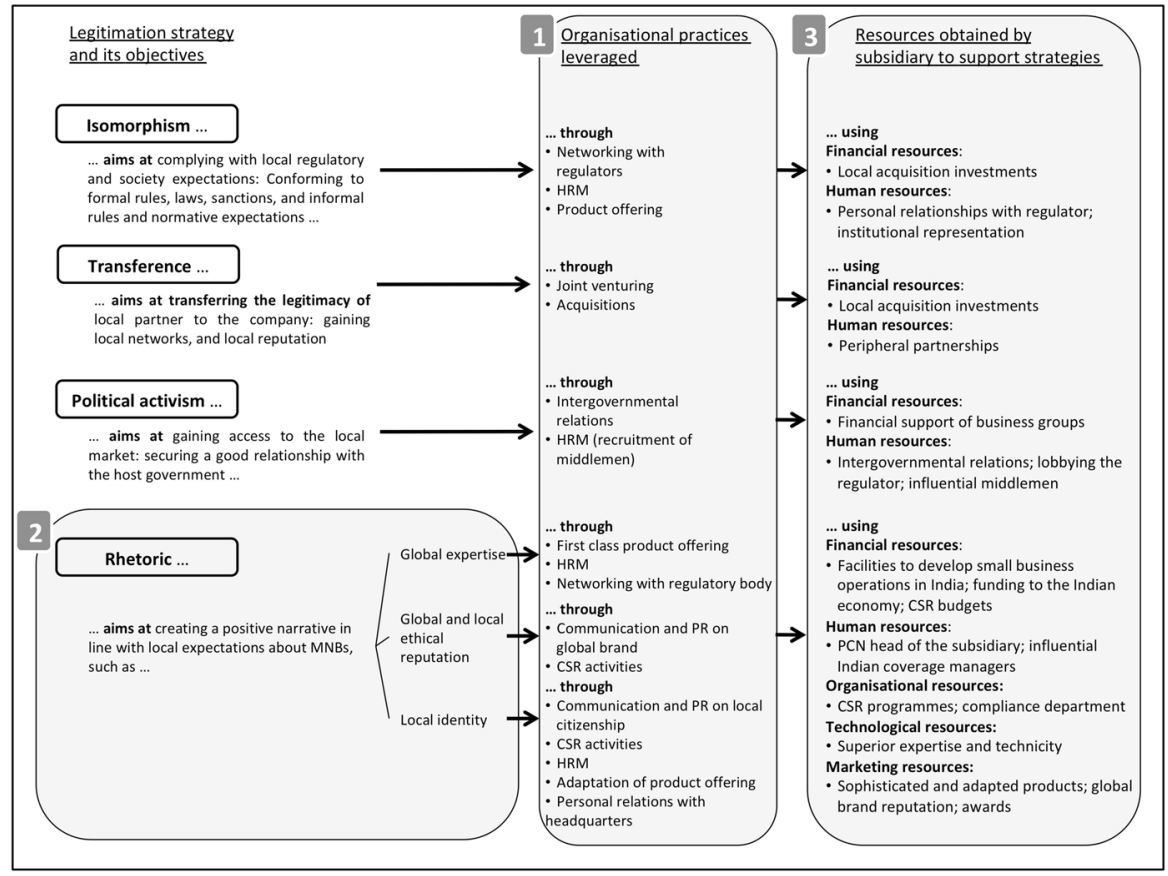

Fig. 1 Legitimation strategies of French MNBs subsidiaries in India-objectives, practices, and resources

strategy at the same time: MNB subsidiaries may become isomorphic (when complying with the regulator and developing an adapted local offering) while benefitting from another entity's legitimacy (when partnering with local actors) and also developing various rhetorical actions (whether localness or globalness is appropriate).

Finally, our results show that country managers occupy an institutional role at the heart of subsidiary decision making and a boundary role at the interface of the MNB and the host country. They manage internal pressures on efficiency and control, along with external demands for legitimacy vis-à-vis multiple sociopolitical actors (i.e., effectiveness goal) using specific organisational practices. In the case of rhetoric strategies, they articulate a global and a local identity by developing dual and potentially ambivalent discourses targeting different actors: localised discourses for local customers, media, and, to some extent, the regulator; globalised (centralised) discourses for the headquarters, the regulator, and, to some extent, local employees. They can mobilise local or foreign identities, depending on whether foreignness is a liability or an asset (Edman 2016; Pant and Ramachandran 2017). Our analysis suggests that acquiring legitimacy in a context of high LOF requires subtlety to understand whether the recipients of legitimation strategies will find value in global (e.g., a world-class ethical brand) or local (e.g., respecting untouchable traditions) attributes. 


\subsection{Implementing Legitimation Strategies Requires Internal Support and Mitigation Competence of Central-Local Tensions}

Any strategy (here, legitimation strategies) requires resources to successfully reach its objectives (resource-based view) (Barney 1991), and as such, strategy fundamentally connects the internal and external perspectives. The four legitimation strategies previously identified require a bundle of financial, human, organisational, technological, and marketing resources (see Fig. 1, right-hand panel). However, obtaining those resources is not easy or automatic. For subsidiaries to gain strategic autonomy without sacrificing their internal support, they must not only ensure they can deliver performance but also allow the headquarters to exert control over their operations. It requires that the country manager be able to mitigate central-local tensions, which is a key success factor of their capacity to use (internal) resources to achieve (external) legitimacy. Global-local tension is a fundamental marker of MNEs' international challenges and decision making, especially in functions such as international marketing, information systems, strategy, and human resources management (Prime and Usunier 2015). The subsidiary is the privileged place of interaction between international and local actors, and it is logically confronted with tensions between the need for local legitimation strategies and for answering internal demands for efficiency and control from headquarters.

In this respect, the organisational practices mobilised at the subsidiary level to manage global (central) and local tensions connect actors from the local and headquarters levels. In particular, French MNBs have consistently appointed parentcountry nationals (i.e., French nationals) as country managers for communication purposes ('the facilitator'), for governance control ('the moderator'), and to be the headquarters' face when negotiating with the regulator ('the representative'). Similarly, French MNBs' Indian managers consider themselves more in an institutional position between the headquarters and the local environment than in the role of a pure local banker. This unique situation (French MNBs vs. other MNBs) highlights that organisational practices to support legitimation strategies abroad could reflect the original home culture of the parent company.

\section{Conclusion}

\subsection{Findings and Contributions}

This paper investigates how service-based MNEs overcome the LOF by seeking legitimacy in the local environment. The empirical study analysed the behaviour of three French MNB subsidiaries operating in India in relation to local sociopolitical actors. Due to the sensitive nature of the activity, MNBs are subject to a high level of scrutiny from local sociopolitical actors, especially the regulator and the media. In addition, because banking in essence is a relational activity, French MNB subsidiaries are likely to face difficulties in integrating local networks. 
Our paper extends existing literature on MNEs' legitimation strategies to overcome the liability of foreignness into distant foreign environment, in three related ways. First, we studied one specific actor central to international business yet often overlooked: multinational banks. We investigated MNBs' interactions with a plurality of sociopolitical actors that constitute the local environment (and did not just focus on one particular actor such as the regulator). Furthermore, we adopted a holistic approach by studying both the sociopolitical and cultural processes behind the legitimation phenomenon. We identified four legitimation strategies: two passive (isomorphism and transference), one reactive (political activism), and one proactive (rhetoric). Each of these strategies refers to specific actors and objectives but can be combined. Second, extant literature on MNEs in distant markets tends to study either the external or internal side of their operations. We looked at the interface between the external and internal environments of MNE subsidiaries. This enabled us to link legitimation strategies in the external environment to some internal considerations. Third, we focused on the micro level of actions by studying actors and not organisational entities. By doing so, we were able to identify a set of organisational practices leveraged by subsidiary-level actors for each legitimation strategy. We connected these practices to the resource-based view framework to ultimately compare the external strategies developed at the subsidiary level with the internal resources required from the headquarters for their implementation. This allowed us to discuss ways to mitigate potential external/internal tensions.

\subsection{Future Research}

Beyond the scope of the present research, we suggest the following avenues for future investigations into legitimation strategies. First, as we suggest using the resource-based view to understand legitimation strategies, future research should address the important question of how to optimise those resources across strategies. For example, it seems relevant to consider the use of specific resources (typically human resources) for various strategies at the same time. Further research should also address the capability or competence of the subsidiary to make the best use of global (standard) versus local (unique) resources, such as-in the case of marketing resources - a global brand reputation that supports a localised product offering.

Second, in terms of data collection, we focused on external and internal interactions of the MNBs; the points of view of the regulator or of local partners could complement the picture. We therefore recommend further studies considering the other side of sociopolitical interactions.

Third, because the confidentiality barrier in the banking industry is high, access to and research on this industry is difficult. Although we applied various triangulation types, and despite our multifaceted results, we cannot claim that the list of organisational practices that reflect legitimation strategies and their implementation is exhaustive. Thus, our research findings could be examined in light of other service industries that share similar features: wholly owned development to retain control over assets, tight regulation, and centrality of the regulator. In this respect, the telecommunication or modern retailing sectors, especially in emerging economies, would be relevant. We also argue in favour of a possible country-of origin effect 
of organisational practices unveiled in this research, as the MNBs investigated all originate from France. In summary, future research could apply a similar research approach in a different environment (e.g., similar industries, various host countries of the same organisation, other countries of origin).

Fourth, data collection occurred from 2014 to 2016, in the midst of the Eurozone sovereign debt crisis, which forced many European MNBs to refocus on their home market. This may have caused biased results_-not necessarily with respect to which organisational practices (the focus of our research) were employed, but perhaps with respect to their prominence or relative importance. Consequently, further research could address the degree to which MNBs resort to each of these strategies, depending on the level of exposure to LOF, using more applied cases than those presented herein.

Fifth, future research could explore the potential links between the home culture of the parent company of the MNB and legitimation strategies, as some supporting organisational practices may reveal a difficulty, or an advantage, of being ethnocentric when growing abroad, especially in emerging markets.

Last, we acknowledge that Indian private banks are quickly catching up through imitation strategies and recruiting talents from foreign MNBs. The window of opportunity negotiated with the regulator might well come to an end. The changes that have occurred in the South Korean banking industry in the past 20 years could provide a useful benchmark against which to reflect on forthcoming industry changes in India. In short, more dynamic, long-term analyses (in contrast to the 'snapshot' perspective that characterises our research) could deepen our understanding of how legitimation strategies (and their internal implementation) can evolve over time.

Acknowledgement This article is based on the corresponding author's doctoral dissertation at ESCP Europe, Paris, under the supervision of Nathalie Prime.

Open Access This article is distributed under the terms of the Creative Commons Attribution 4.0 International License (http://creativecommons.org/licenses/by/4.0/), which permits unrestricted use, distribution, and reproduction in any medium, provided you give appropriate credit to the original author(s) and the source, provide a link to the Creative Commons license, and indicate if changes were made.

\section{Appendix 1: Interview Guide}

The interview guide is composed of three series of questions.

The first series relates to the host environment of the subsidiary and aims at identifying the external interactions with key legitimacy providers (i.e., the regulator, the media, civil society, competitors, and clients):

- Can you present the activities of the bank in India? What were the motivations to operate in India? Is India a strategic market for the bank?

- Which clients do you target? How do you approach your clients?

- What differentiates your bank compared to other foreign banks? Does the global reputation of the bank have an impact on Indian clients' perception? 
- What is your relationship with the regulator? How do you approach it? Do you resort to diplomatic networks to interact with local political and regulatory spheres?

- How do you differentiate from local banks? What is the added value brought by foreign banks compared to local banks?

- What are your relationships with the press? How do you communicate? What CSR strategy do you develop at the local level? Who is in charge of communication and CSR?

The second series of questions relates to the organization and management of the subsidiary and aims at (1) better understanding organizational practices mobilized in the interactions with the client and (2) within the subsidiary (i.e., with employees, and the $\mathrm{CEO})$ :

- How are your Indian operations organised? How many branches do you have in the country?

- How many employees do you have in the subsidiary? What is the ratio between expatriates and locals? What are the positions of expatriates? Who are the senior bankers and how do you recruit them? What are the career opportunities offered to local employees?

- What makes your bank an attractive employer? What advantages do you propose to attract local talents?

- How is the performance of employees and senior bankers evaluated? What kind of performance evaluation tools do you use?

- What is the role of the CEO of a subsidiary? What are the daily tasks related to managing a subsidiary? Considering a typical week, how do you allocate your time to key activities? Whom do you report to?

The third part relates to the relationships within the intraorganisational network of the subsidiary and aims at identifying the internal interactions and organizational practices mobilized to support them:

- To whom do the senior bankers report? Has a global structure been implemented? What is the role of the regional hub within the group and how does it work with the subsidiary?

- Where is the local development strategy designed? Who validates its implementation? How does the subsidiary coordinate with the headquarters and other subsidiaries of the group? In case of disagreements between the subsidiary and the headquarters, how is this conflict managed?

- What is the role of the compliance and risk management department? How do they interfere with the subsidiary activities?

- What is the language used within the group? 


\section{References}

Aichner, T. (2014). Country-of-origin marketing: A list of typical strategies with examples. Journal of Brand Management, 21(1), 81-93.

Barney, J. (1991). Firm resources and sustained competitive advantage. Journal of Management, 17(1), 99-120.

Barreto, I., \& Baden-Füller, C. (2006). To conform or to perform? Mimetic behaviour, legitimacy-based groups and performance consequences. Journal of Management Studies, 43(7), 1559-1581.

Barros, M. (2014). Tools of legitimacy: The case of the Petrobras corporate blog. Organization Studies, 35(8), 1211-1230.

Bhaumik, S. K., Owolabi, O., \& Pal, S. (2018). Private information, institutional distance, and the failure of cross-border acquisitions: Evidence from the banking sector in Central and Eastern Europe. Journal of World Business, 53(4), 504-513.

Bitektine, A., \& Haack, P. (2015). The "macro" and the "micro" of legitimacy: Toward a multilevel theory of the legitimacy process. Academy of Management Review, 40(1), 49-75.

Buckley, P. J., \& Ghauri, P. (2004). Globalisation, economic geography and the strategy of multinational enterprises. Journal of International Business Studies, 35(2), 81-98.

Buckley, P. J., Munjal, S., Enderwick, P., \& Forsans, N. (2016). Cross-border acquisitions by Indian multinationals: Asset exploitation or asset augmentation? International Business Review, 25(4), 986-996.

Chan, C. M., \& Makino, S. (2007). Legitimacy and multi-level institutional environments: Implications for foreign subsidiary ownership structure. Journal of International Business Studies, 38(4), 621-638.

Chen, G., Chittoor, R., \& Vissa, B. (2015). Modernizing without westernizing: Social structure and economic action in the Indian financial sector. Academy of Management Journal, 58(2), 511-537.

Claessens, S., Demirgüç-Kunt, A., \& Huizinga, H. (2001). How does foreign entry affect domestic banking markets? Journal of Banking and Finance, 25(5), 891-911.

Claessens, S., \& van Horen, N. (2012). Being a foreigner among domestic banks: Asset or liability? Journal of Banking and Finance, 36(5), 1276-1290.

Cole, S. (2009). Fixing market failures or fixing elections? Agricultural credit in India. American Economic Journal: Applied Economics, 1(1), 219-250.

Deephouse, D. (1996). Does isomorphism legitimate? Academy of Management Journal, 39(4), 1024-1039.

Denzin, N. K. (1978). The research act: A theoretical introduction to sociological methods. New York: McGraw-Hill.

DiMaggio, P., \& Powell, W. (1983). The iron cage revisited: Institutional isomorphism and collective rationality in organizational fields. American Sociological Review, 48(2), 147-160.

Dörrenbächer, C., \& Geppert, M. (2006). Micro-politics and conflicts in multinational corporations: Current rebates, re-framing, and contributions of this special issue. Journal of International Management, 12(3), 251-265.

Dörrenbächer, C., \& Geppert, M. (2012). Politics and power in the multinational corporation: The role of institutions, interests and identities. Cambridge: Cambridge University Press.

Dunning, J. (2009). Explaining changing patterns of international production: In defence of the eclectic theory. Oxford Bulletin of Economics and Statistics, 41(4), 269-295.

Eden, L., \& Miller, S. R. (2004). Distance matters: Liability of foreignness, institutional distance and ownership strategy. In M. Hitt \& J. L. C. Cheng (Eds.), Theories of the multinational enterprise: Diversity, complexity and relevance (Advances in international management, Volume 16). Bingley: Emerald Group Publishing.

Edman, J. (2016). Reconciling the advantages and liabilities of foreignness: Towards an identity-based framework. Journal of International Business Studies, 47(6), 674-694.

Ehrnström-Fuentes, M. (2016). Delinking legitimacies: A pluriversal perspective on political CSR. Journal of Management Studies, 53(3), 433-462.

Eisenhardt, K. M. (1989). Building theories from case study research. Academy of Management Review, 14(4), 532-550.

Eisenhardt, K. M., \& Graebner, M. E. (2007). Theory building from cases: Opportunities and challenges. Academy of Management Journal, 50(1), 25-32. 
Elg, U., Ghauri, P. N., \& Schaumann, J. (2015). Internationalization through sociopolitical relationships: MNEs in India. Long Range Planning, 48(5), 334-345.

Gaur, A. S., \& Lu, J. W. (2007). Ownership strategies and survival of foreign subsidiaries: Impacts of institutional distance and experience. Journal of Management, 33(1), 84-110.

Gormley, T. A. (2010). The impact of foreign bank entry in emerging markets: Evidence from India. Journal of Financial Intermediation, 19(1), 26-51.

Hadjikhani, A., Lee, J.-W., \& Ghauri, P. N. (2008). Network view of MNCs' socio-political behavior. Journal of Business Research, 61(9), 912-924.

Hadjikhani, A., \& Sharma, D. D. (1999). A View on political and business actions. In P. N. Ghauri (Ed.), International marketing and purchasing (advances in international business and marketing, volume 9). New York: JAI Press.

Hennart, J.-F. (2012). Emerging market multinationals and the theory of the multinational enterprise. Global Strategy Journal, 2(3), 168-187.

Holburn, G. L., \& Vanden Bergh, R. G. (2008). Making friends in hostile environments: Political strategy in regulated ndustries. Academy of Management Review, 33(2), 521-540.

Jeon, B. N., Pía Olivero, M., \& Wu, J. (2013). Multinational banking and the international transmission of financial shocks: Evidence from foreign bank subsidiaries. Journal of Banking and Finance, 37(3), 952-972.

Johanson, J., \& Vahlne, J. (2009). The Uppsala internationalization process model revisited: From liability of foreignness to liability of outsidership. Journal of International Business Studies, 40(9), 1411-1431.

Johnson, G., Whittington, R., Scholes, K., Angwin, D., \& Regner, P. (2017). Exploring strategy, text and cases. Harlow: Pearson.

King, B. G. (2008). A political mediation model of corporate response to social movement activism. Administrative Science Quarterly, 53(3), 395-421.

Kostova, T. (1998). Quality of inter-unit relationships in MNEs as a source of competitive advantage. In M. Hitt, J. Ricart, \& R. Nixon (Eds.), New managerial mindsets: Organizational transformation and strategy implementation. Chichester: Wiley.

Kostova, T., \& Roth, K. (2002). Adoption of an organizational practice by subsidiaries of multinational corporations: Institutional and relational effects. Academy of Management Journal, 45(1), 215-233.

Kostova, T., Roth, K., \& Dacin, M. T. (2008). Institutional theory in the study of multinational corporations: A critique and new directions. Academy of Management Review, 33(4), 994-1006.

Kostova, T., \& Zaheer, S. (1999). Organizational legitimacy under conditions of complexity: The case of the multinational enterprise. Academy of Management Review, 24(1), 64-81.

La Porta, R., Lopez-De-Silanes, F., \& Shleifer, A. (2002). Government ownership of banks. Journal of Finance, 57(1), 265-301.

Lachaier, P., \& Clementin-Ojha, C. (2008). Divines richesses: Religion et économie en monde marchand indien. Paris: Ecole française d'Extrême-Orient.

Li, J., Jiang, F., \& Shen, J. (2016). Institutional distance and the quality of the headquarters-subsidiary relationship: The moderating role of the institutionalization of headquarters' practices in subsidiaries. International Business Review, 25(2), 589-603.

Li, Y., Peng, M. W., \& Macaulay, C. D. (2013). Market-political ambidexterity during institutional transitions. Strategic Organization, 11(2), 205-213.

Lu, J., \& Xu, D. (2006). Growth and survival of international joint ventures: an external-internal legitimacy perspective. Journal of Management, 32(3), 426-448.

Meyer, K. E., Ding, Y., Li, J., \& Zhang, H. (2014). Overcoming distrust: How state-owned enterprises adapt their foreign entries to institutional pressures abroad. Journal of International Business Studies, 45(8), 1005-1028.

Mian, A. (2006). Distance constraints: The limits of foreign lending in poor economies. Journal of Finance, 61(3), 1465-1505.

Naudet, J., \& Dubost, C. (2016). The Indian exception: The densification of the network of corporate interlocks and the specificities of the Indian business system (2000-2012). Socio-Economic Review, 26, 405-434.

Pant, A., \& Ramachandran, J. (2017). Navigating identity duality in multinational subsidiaries: A paradox lens on identity claims at Hindustan Unilever 1959-2015. Journal of International Business Studies, 48(6), 664-692.

Peng, M. W., Sun, S. L., Pinkham, B., \& Chen, H. (2009). The institution-based view as a third leg for a strategy tripod. Academy of Management Perspectives, 23(3), 63-81. 
Prime, N., \& Usunier, J. (2015). Marketing international: marchés, cultures et organisations. Paris: Pearson Education.

Rathert, N. (2016). Strategies of legitimation: MNEs and the adoption of CSR in response to host-country institutions. Journal of International Business Studies, 47(7), 858-879.

Salomon, R., \& Wu, Z. (2012). Institutional distance and local isomorphism strategy. Journal of International Business Studies, 43(4), 343-367.

Santangelo, G. D., \& Meyer, K. E. (2017). Internationalization as an evolutionary process. Journal of International Business Studies, 48(9), 1114-1130.

Scott, W. R. (2014). Institutions and organizations: Ideas, interests, and identities. Stanford: Sage Publications.

Selznick, P. (1996). Institutionalism “old” and "new”. Administrative Science Quarterly, 41(2), $270-277$.

Sheth, J. N. (2011). Impact of emerging markets on marketing: Rethinking existing perspectives and practices. Journal of Marketing, 75(4), 166-182.

Singh, J., Tucker, D., \& House, R. (1986). Organizational legitimacy and the liability of newness. Administrative Science Quarterly, 31(2), 171-193.

Suchman, M. (1995). Managing legitimacy: Strategic and institutional approaches. Academy of Management Review, 20(3), 571-610.

Wu, Z., \& Salomon, R. (2017). Deconstructing the liability of foreignness: Regulatory enforcement actions against foreign banks. Journal of International Business Studies, 48(7), 837-861.

Yin, R. (2014). Case study research: Design and methods. Thousand Oaks: Sage Publications.

Yiu, D., \& Makino, S. (2002). The choice between joint venture and wholly owned subsidiary: An institutional perspective. Organization Science, 13(6), 667-683.

Zaheer, S. (1995). Overcoming the liability of foreignness. Academy of Management Journal, 38(2), 341-363.

Zhao, M., Park, S. H., \& Zhou, N. (2014). MNC strategy and social adaptation in emerging markets. Journal of International Business Studies, 45(7), 842-861.

Publisher's Note Springer Nature remains neutral with regard to jurisdictional claims in published maps and institutional affiliations. 